\title{
Logos, Ethos and Pathos in Albanian Political Discourse
}

\author{
Ardita Dylgjeri, Phd Candidate
}

Doi:10.5901/jesr.2014.v4n4p55

\author{
"Aleksander Xhuvani" University, Elbasan, Albania
} Email address: arditadylgjeri@live.com

\section{Abstract}

Over 2,000 years ago the Greek philosopher Aristotle argued that there were three basic ways to persuade an audience of your position: Logos, Ethos, and Pathos. Even though several new attempts and studies have merged within the field of discourse analysis, the Triad persuading approach is still considered and examined as a crucial and inevitable component of political reasoning. By examining several pre-election political discourses in Albania, we will try to highlight the linguistic means, which are used by each politician to present the three dimensions of the argumentative persuasion - Logos, Ethos, and Pathos. In addition, we aim at comparing the ways that different political leaders build rationale and logical discourses; how they present their own personality; what methods they appeal to impact electorate emotionally.

Keywords: Logos, Ethos, Pathos, political discourse, argumentation.

\section{Introduction}

Rhetoric may be defined as the faculty of observing in any given case the available means of persuasion. (Aristotle)

Every time we use language (in speech or in writing), we engage in a rhetorical act. Whenever we use language, we have an intention: a message to communicate or a goal to achieve. In fact, a useful modern definition of rhetoric is simply the intentional use of language to influence an audience. It is obvious that rhetoric serves as the backbone of the political discourse. Michel Meyer concludes that rhetoric is "the analyses of connection of means and goals by help of discourse" (Meyer, 2001, p. 22)

As it is known, political discourse is a specific subject of interdisciplinary study and of the sciences such as political science, sociology, psychology, socio-linguistics and other. As a result, political discourse analysis is considered not only as a mere method, but as a cross discipline, a discipline in its own right in which a wide range of other fields of thought and study are encompassed.

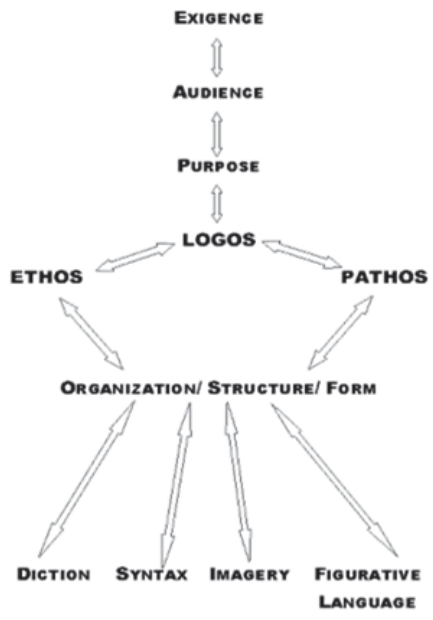

In a political discourse analysis, two kinds of intentions have to be considered: first, communicative intention, and, then, persuasive intention. The fulfillment of those intentions is achieved by a successful persuasive-communicative action. The psychological, philosophical, and logical aspects derived from the pragma-rhetorical perspective are crucial in 
view of its applications in several practical domains.

Any type of argumentation and persuasion is an attempt to impact on interlocutors, to persuade them that the thesis of a speaker (writer) is valid, and to make them to be engaged in the activities in speaker's (writer's) favor. Logos, Ethos and Pathos are inevitable components of reasoning but the combination of all of them enables a speaker successfully complete his/her discourse and achieve his/her goal.

Thus, the paper studies the force of word, internal consistency of the message in a specific communication situation, where it is exclaimed or in the other words, in specific institutional, social and cultural strata.

To better, illustrate the effect of the Triade: Logos, Ethos, Pathos and the organization of discourses, one may also take into consideration the above schema.

\section{Logos, Ethos, Pathos}

Over 2,000 years ago the Greek philosopher Aristotle argued that there were three basic ways to persuade an audience of your position: Logos, Ethos, and Pathos. Even though several new attempts and studies have merged within the field of discourse analysis, the Triad persuading approach is still considered and examined as a crucial and inevitable component of political reasoning

Argumentative analyses aims at describing and explaining of all those means and methods, by help of which the discourse of a writer or a speaker endeavours to impact on audience. The goal of argumentative writing is to persuade an audience that the ideas of a writer are valid, or more valid than someone else's. It consists of three important inevitable components: Logos, Ethos, and Pathos. For the first time the three elements of argumentation were presented by Aristotle.

- Logos, as an important element of argumentative judgment, means persuading by the use of reasoning, which includes critical cognition, analytical skills, good memory, and purposeful behavior, which is the most important argumentation. (Friedenberg, 1997., pp. 61-91). For Aristotle Logos is rationale, logical and argumentative discourse. Ethos is a style of a speaker by help of which he or she appeals to and tries to attract the attention of audience to earn their faith.

- Ethos refers to the trustworthiness or credibility of the writer or speaker. If the speaker is persuasive, the audience follows him or her. In his discourse, Aristotle calls Ethos the face of the orator that would affect audience by words, in other words it is a "face created by the discourse." This is conditioned by the fact that the orator earns the credibility only in case if his or her arguments are competent, reliable, fair and frank.

The impact of ethos is often called the argument's 'ethical appeal' or the 'appeal from credibility. Maingueneau, describes Ethos as follows: "Orator's Ethos is related with his/her speech and the role that corresponds to his/her discourse but not the individual" (Maingueneau, 1993., p. 66)

According to Ruth Amossy, one of the most distinguished scientists and linguists, there are two types of Ethos: Preliminary Ethos and Discourse Ethos. Preliminary Ethos is what the audience preliminary knows about the speaker (writer), in other words, what it knows about speaker's authority, marital status and social status. Some orators attempt to ground on it and use such Ethos in his/her favor during a discourse, in case if it is positive. However, in case if the Preliminary Ethos is negative the speaker does his/her best to revoke such an impression of people on him/her. As to the Discourse Ethos, it is the Ethos created immediately for the specific situation and during the discourse (Amossy, 2000, p. 63)

- Pathos is directly linked with an audience. Audience is a collective subject of speakers on which an orator tries to impact by own argumentation. Thus having audience is one of the necessary conditions for communication. In Aristotle's "Rhetoric" Pathos is the power with which the writer's (speaker's) message moves the audience to his or her desirable emotional action. Thus a good orator should know for sure which emotion would effectively impact on audience considering their social status, age and other features. It is important to know not only how the orator can express but how he or she can by help of discourse cause favorable emotions, like anger, insult, empathy, fear, confusion, etc. (Amossy, 2000, p. 178)

\section{A Pragma-Rhetoric Approach to Political Discourse Analysis}

It appears that Rhetoric is as it were an offshoot of Dialectic and of the science of Ethics, which may be reasonably called Politics." (Aristotle, pp. 1356a 15-30)

Pragmatics and rhetoric are two crucial fields of study in political discourse analysis. The rhetoric aspect is 
essentially devoted to a study of order, i.e. to the planning of discourse, which means the production of the structure of discourse in a dynamic perspective, given the fact that real discourse is what is finally performed as discourse with all the moves made in the process (Dascal, 1999, pp. 108-110)

Pragma-rhetoric is not isolated from logic, on the contrary, it takes logic at the very ground in discourse construction, but the crucial notion of the intention to persuade links rhetoric with pragmatics in a global intentional architecture of individuals, distinguishing and combining at the same time communicative intention and persuasive intention.

\subsection{What is the content of persuasive intentions?}

"Wherever there is persuasion, there is rhetoric. And wherever there is meaning, there is persuasion" (Burke, 1969, p. 72)

We are basically speaking about a very stable kind of intention, persistent through all the process of elaboration and performance of a discourse, oriented to a particular type of behavior on the part of the hearers (as communicative intentions, persuasive intentions lead to a particular kind of individual social actions), namely, their persuasion in terms of the acceptance of beliefs and goals expressed by the speaker (or, at least, a significant reduction in the distance between the mental states manifested by the speaker and those of the hearers, naturally intending to lead hearers to action.

Pre-election campaign discourse differs from other discourses by the following: during pre-election periods, the discourses of politicians and the disposition of their personality are the subjects of the greatest attention. Politicians should persuade electorate in the validity of their position and make the audience believe they are offering the best decisions or actions for supporting the candidate in future.

...But certainly, the people on June 23rd will have to chose between 2 teams. The fatigued puppet team of the PD owner and our national Renaissance team... (Rama, Evis Kushi, vlerë e shtuar në Skuadrën Kombëtare të Rilindjes, 2013)

In the above paragraph, the speaker aimed to reveal the "moral and political or professional potential" of the candidates, who were represented in the lists of the main opponent political forces participating in the electoral campaign of 2013. Having shown before the corruption and the power abuse of the at the time majority he showed out the professional integrity of the MP-s, the Socialist Party was proposing:

...Evis Kushi for the example she is giving to the Albanian academic ambient by being directly involved in the efforts for an Albanian Renaissance... The envolvement of Evis Kushi in the National Renaissance Team is to the Socialist Party in Elbasan a reason more to be proud in front of Elbasan and entire Albania, for this wining team.(Rama, Evis Kushi, vlerë e shtuar në Skuadrën Kombëtare të Rilindjes, 2013)

The building of the credibility of the representing MP candidates most of times was closely related with the European Union integration process, consequently:

Edi Rama, said no (to the integration process A.D.), he is not our enemy, but what should we consider the one that denies to the nation the European integration? This man cannot be and is not friendly to Tirana and Albania. (Basha,2013)

The more argumentative and persuasive their discourses are, more become the chances for politicians to win elections because "to impact on audience with words means change its existing mental status" (Charaudeau, 2005, $p$. 16). That is why in pre-election period every politician absolutely tends to use argumentation, or in other words, as Aristotle says, different strategies of the art of persuasion to achieve the favorite goal. For achieving the goal an orator should take into account and consider the values, opinions and faith of the audience to which he/she appeals to.

The one who governed Tirana for 11 years became an obstacle to the European integration, inconceivably left Tirana out from the list of European Union member countries capitals. (Tanushi, 2013)

As seen above the majority tented to provoke emotional attitude towards the obstructionism the opposition engaged to the integration program. The goal, the intention to gain electoral ground, had to be achieved at every cost. The strategy was to provoke emotional reactions, not to base their campaign to touchable realities. 


\section{Practical Examples of Logos, Ethos and Pathos in Albanian Political Discourse}

Albanian political discourse has the inclination to mix the three components. Being directly affected by totalitarian discourse the division between allies and enemies, it is mostly the clash between the good and evil.

Though they used to consider each - other as filthy persons, they urge each - other to unite. Let they consider themselves as they wish, we will remain a Party of values... whoever joins us, will join a set of values (Berisha, 2013) It is a complicated situation; in fact, it all begins with the professional freedom. The other factors are decisive, but the professional freedom here (in Albania A. D.) is completely violated on political ground, in fact not political but on party membership basis, completely electoral; these are damaging every day passing, the education system, the relationship between the teacher and the education institution, among the teachers themselves, the education institution and the community, the community and the children's future. The first thing to do is to give the teachers back their professional freedom. To create a teachers' recruitment process coordinated with the community. (Rama, 2013)

Sometimes ethos is veiled under the sophisticated pathos of the speaker:

MR. Rama mentioned a special taxes agency. None of you has read more has as we were forced about NEP, about Lenin's special taxes policy, after the October Revolution, to deprive the wealthy from their fortune, for Lenin's special agency, about NEP policy. (Rama agjenci speciale per taksat si Lenini me NEP-in, 2013)

Injustice lies in this society's foundations; we have to amend it. It is unjust that your parents, common public or private employees, pay more taxes than the MP-s, ministers and prime ministers. This must change and we will change it ("Një Rilindje Shqiptare", me dhe për të rinjtë, 2013)

In the first case, the tendency is to differ us from them. In one side we have the good versus evil (values versus moral filthiness, freedom versus political corruption).

In the second case both parts press on the emotional reaction of the audience. The socialist leader presses on the unjust distribution of wealth and the unfair fiscal system. The ex-premier presses on the Marxist oriented electoral program.

Both speakers tend to impose their point of view by pressing on audience's emotional reaction. They hope that the Pathos on their discourse, emphasizing the injustice towards all, by reminding them the possible overthrowing of the democratic political system. Strangely, Ethos is mixed with the typical effects of Pathos. As mentioned before, Ethos is based on building credibility in the eyes of the audience, by not only distorting the stances of the opposite counterpart, but also by offering miraculous solutions, which would amend the unjust. Ethos, in the Albanian political discourse is rarely based on arguing or debating. Usually, it is subdued to Pathos, since it appears that the Albanian politicians and the Albanian audience are influenced more by the emotions than the facts. Even though facts are offered, they are hyperbolized; they are not confronted or checked. In many occasions, they are even not true.

\section{Conclusions}

By the end of this paper, it may be concluded that:
A political phenomenon becomes tangible and discussable only after it has been expressed in words. Thus, politics and language are closely related to each other, depending on each other and using each other at the same time.
Political discourse analysis can be examined as political communication viewed linguistically and of linguistics viewed communicatively.

The most crucial characteristics of political discourse is argumentation and persuasion. Through their speeches, politicians aim at making the audience believe that their ideology, beliefs, and opinions are the best one to be offered.

Aristotelian Triad Logos, Ethos and Pathos and its several linguistic means of expression make the speech acts, especially political speech acts argumentative and it is very important for understanding the messages and impacting the audience.

\section{References}

Amossy, R. (2000). Largumentation dans le discours. Discours politique, littérature didées, fiction. . Paris: Nathan Universite . Aristotle. Rhetoric (Vol. I). (W. R. Roberts, Trans.) http://rhetoric.eserver.org.

Basha, L. (2013, May 13). Edi Rama armik i shqipetareve. Retrieved May 14, 2014, from Gazeta Panorama: http://www.panorama.com 
.al/2013/05/13/basha-edi-rama-armik-i-shqiptareve/

Berisha, S. (2013, January 18). Vlerat ne vend te funderrinave. Rilindja Demokratike (6438), p. 3.

Burke, K. (1969). A rhetoric of motives. London, England: Univ of California Press.

Charaudeau, P. (2005). Le discours politique: les masques du pouvoir. Vuibert, .

Dascal, M. a. (1999). The marriage of pragmatics and rhetoric. Philosophy \& rhetoric 32, no. 2 , 107-130.

Friedenberg, R. V. (1997.). Communication consultants in political campaigns: Ballot box warriors. Greenwood

Publishing Group.

Maingueneau, D. ( 1993.). Le contexte de l'oeuvre littéraire: énonciation, écrivain, société. . Bordas.

Meyer, M. (2001). "Between theory, method, and politics: positioning of the approaches to CDA. In M. Meyer, \& R. Woodak (Eds.), Methods of critical discourse analysis (pp. 14-31). Sage Publiications Ltd.

Rama agjenci speciale per taksat si Lenini me NEP-in. (2013, January 17). Rilindja Demokratike , p. 3

Rama, E. (2013, February 25). "Një Rilindje Shqiptare", me dhe për të rinjtë. Retrieved May 7, 2014, from ps.al: http://www.ps.al/tereja/nje-rilindje-shqiptare-me-dhe-per-te-rinjte-25-02-2012/

Rama, E. (2013, March 07). Do u kthejme arsimtareve lirine e profesionit. Retrieved May 19, 2014, from ps.al: http://www.ps.al/tereja/rama-do-tu-kthejme-arsimtareve-lirine-e-profesionit

Rama, E. (2013, March 24). Evis Kushi, vlerë e shtuar në Skuadrën Kombëtare të Rilindjes. Retrieved May 12, 2014, from ps.al: http://www.ps.al/te-reja/evis-kushi-vlere-e-shtuar-e-skuadres-sone-kombetare-te-rilindjes/

Tanushi, L. (2013, February 11). TemA TVI Berisha: PD ka mbështetjen më të madhe që prej '96-ës (kur manipuloi votat) (VIDEO). Retrieved May 12, 2014, from Gazeta Tema: http://www.gazetatema.net/web/2013/02/11/berisha-tirana-do-te-dije-si-te-votojeme-23-qershor-rama-mosmirenjohes-ndaj-kryeqytetasve/ 